\title{
Title: The Place of Television Programme Formats
}

\section{Authors: Albert Moran and Karina Aveyard}

Albert Moran is a Professor of Media Studies in the School of Humanities at Griffith University in Brisbane. He has published extensively in such areas as TV format trade, Australian film and television history, and media geography.

Karina Aveyard is a Lecturer in Media, Arts and Humanities in the School of Film, Television and Media Studies at the University of East Anglia.

\section{Abstract}

'Formats are king!' or so declares the trade publication TV Formats Weekly (Brzoznowski 2011: 4). Indeed there are solid grounds for such claims regarding the current place of this type of programming in television schedules around the world. Formats are perceived to be highly effective in mitigating commercial uncertainties brought about by multi-channelling, and the social uncertainties associated with cultural mobility and de-territorialization. However, their ubiquity also presents us with an interesting geo-cultural paradox. As an industrial commodity, formats have a highly mobile, readily transferable quality. However, as a social and cultural artefact, they can take on a form that is specific to the particular community for which they are adapted. In this article, we explore the characteristics of these multi-layered geographic interrelationships and consider the conceptual value (and limitations) of some of the key terms around which the role and function of formats have been understood.

\section{Keywords}

Television formats

Globalisation

Parochial internationalism

Reg Grundy 


\section{Introduction}

It is over 15 years since the TV programme format Big Brother was devised in the Netherlands by John de Mol for his production company Endemol. Beginning in the Netherlands and shortly thereafter giving rise to a string of franchised productions across the world, Big Brother is possibly the most watched programme in world television history. The accumulated audience for its different national versions produced to 2005 (when the format was at the height of its appeal), was estimated at a staggering 740 million viewers. Economically, it also proved to be an extremely valuable franchise, generating more than US $\$ 10$ billion in profits worldwide in the same period (Bazelgette 2005: 316-29). The phenomenal success of the show also heralded the maturation of television programme formats as an industry craft and cultural enigma that now spans a very wide variety of forms and genres. However, as Goldsmith et al. (2010) point out, the growth of franchising has given rise to a further decoupling of the spatial relationship between programme devising, production and broadcast. These developments may be understood as signalling the triumph of media without frontiers. However, such an assertion is not straightforward, and we must also contend with the way in which formats underline the continued importance of programming with domestic or home-grown qualities (Moran and Malbon 2006; Tunstall 2008; Moran 2009a).

Taking up this concern, the article investigates the geo-cultural parameters and terminology of television programme formats. Media frontiers can be cultural as much as they are physical, such that any spatial analysis of the nature of formats must consider these dual elements. Our enquiry is divided into three sections. The first outlines the broader contexts in which the geographic and cultural significance of programme franchising is located. We consider the larger economic, political and cultural forces that have shaped the terrain within which formats circulate. In particular we explore the paradoxical nature of their industry commonality on the one hand and socio-cultural intimacy on the other. This is followed by analysis of the conceptual value (and limitations) of two frameworks, which have been deployed at different times in an attempt to capture the inherent duality of formats - parochial internationalism and the global/local nexus. While the former term is now somewhat outdated, we argue it offers a productive means of understanding the versatility of formats. Further, we suggest it serves to illustrate how the second, and more current, global-local demarcation struggles to effectively encapsulate the multiplicity of formatted programmes.

\section{The Global Terrain of Television Formats}

There is no doubt that over the past half century or so, a period itself coincident with the world-wide ascendency of television, has seen dramatic and significant economic, social and political change. In the West, the 'Long Boom' of the post WWII years was brought to an end in the 1970s by international events that included the rapid rise in the trade of manufactured goods, two oil crises, a major stock-market crash and the collapse of the Bretton Woods system of monetary management (Middleton 2000). Among the most public signs of these realignments has been the rise of unemployment in Western economies, the steady erosion of the social welfare state, trade liberalization, the end of the Cold War and the rise of Asia, most especially the People's Republic of China and India (Galtung 1993; Giddens 2000). War, physical disasters, and the post GFC Recession, along with changing labour markets and tourism, have led to an ever-increasing mobility of populations both within and between nation states (Castells 1996; Miller 1993). At a cultural level there have been equally significant developments. These include the increased accessibility of transportation and 
communications, which are profoundly changing populations' relationships with space and time. Various explanations have been offered as a means of making sense of these international flows - most notably the notion of globalisation (Robertson 1992; Giddens 2000; Bhagwati 2004).

The idea of globalisation rests on acceptance of the existence of a worldwide system of economic, cultural and political interdependence, one which has eroded the autonomy and power of the nation-state (Castells 1996, Giddens 2000, Horsman and Marshall 1994, Robertson 1990). Often linked with these arguments are claims regarding the universalisation of culture driven in particular by the globalisation of the media of mass communications. Theorists of the media as early as Guback (1969) through to Miller et al. (2001) have suggested that the increasing tendency for television programmes and films from the West (especially the US) to dominate the national audiovisual systems of other countries is leading to the breakdown of indigenous or national cultures. Ritzer has argued a similar point in terms of a 'MacDonaldization' of cultures across the planet (2004). However, at the same time, the perceived displacement of national culture by a global culture has also been cause for celebration in the writings of a post-modernist tradition that runs from McLuhan (1962) to Rantanen (2005). For our purposes, it is significant that both camps rest on the notion of identifiable 'national' cultures being eclipsed by homogenizing worldwide influences.

More recent analysis has tended to be more nuanced. Television scholars have drawn attention to the fact that nations and the cultures within them mediate and absorb the influences of media globalisation in very specific and different ways (Stetka 2012, Zhang 2011). Further, Esser's research on programme formats has demonstrated that the local cannot readily be 'reduced to the national' (2010: 289). Yet some common threads remain - namely the perceived disappearance of cultural difference facilitated by what is now seen to be a highly internationalised media order. Paradoxically, it is this same internationalised media order has given rise to the television format - a complex cultural and economic commodity which, as we will see, calls into question some of the claims regarding colonisation.

Television schedules around the world are typically filled with programming from one of three main sources. First, is content devised, produced and broadcast only within its territory of origin (such as news, current affairs, soaps and so on). Alongside this category sits two other programme types that are characterized by a greater international transferability and sales potential - canned (or finished) programming and formats (Waisbord 2004). Both canned and formatted programmes regularly begin life as a ratings success within their home territory, and this often helps drive subsequent international sales. As the term suggests, canned programming is sold as a completed product ready for re-broadcast. In some instances it is customised but this is generally limited to minor reworkings such as dubbing or subtitling for foreign language territories. With formats, on the other hand, what is on-sold is the template for the programme's re-production rather than a show ready for transmission. This template a set of franchised knowledge and services - distils the experiences and skills of the programme's original creators and allows the programme to be adapted and produced for broadcast in other territories (Moran 1998: 6-12, Moran and Malbon 2006).

While pre-formulation is part of the appeal of formats, these templates are also flexible capable of being moulded to suit the particular social inflexion and cultural nuances of the broadcaster and territory for which it is remade (Esser 2010). The duality of the television format can be understood as a text-performance relationship, whereby a codified composition 
(literary, musical, dramatic and so on) is seen to be capable of many different kinds of performances that diverge according to setting, audiences, creative interpretation and a host of other variables (Navarro 2011, 23-38). Borrowing a phrase from literary researcher, Linda Hutcheon, we can say the television program format facilitates repetition without replication (2006: xvi). In this sense, the television format may be regarded as an unfinished, unbounded and even universal construct. It has a transferable, go-anywhere quality that might, inter alia, be cited as evidence of a world-wide television system (Beilby and Harrington 2008, Chalaby 2010, Havens 2006, Moran 2009a, Selznick 2008).

However, another key characteristic of the franchising and remaking process is that the programme is often modified in such a way as to seem familiar or domestic in origin. The content is shaped to fit the particular world of its target audience - the new programme's performers and participants will, for the most part, be ethnically familiar; speak one or other in the dominant territorial languages; be visually and culturally anchored in recurring, everyday locations; deal with recognisable situations and issues; and behave in customary and familiar ways. Audiences are understood to have a preference for programmes that are attuned to their sense of who they are (Tunstall 2008: $x$ ), and format producers are careful to ensure that this familiarity is obviously and vividly represented in the adapted programme.

So while television programme formats have a world-wide footloose quality, they also have the capacity to take root and nativize themselves in a myriad of different audience contexts for different broadcasters and geographic territories. This aspect of formats presents us with an intriguing but at times perplexing duality. Focusing on terminology, the next two sections of this article focus on the language and concepts through which scholars and the television industry have attempted to describe and understand the multi-faceted cultural and physical footprint of formats. We look specifically at the term parochial internationalism and the popular global/local nexus.

\section{Parochial Internationalism}

'Parochial Internationalism' is a term coined by Australian television format mogul Reg Grundy to describe the characteristics inherent to the marketing, licensing and adaptation of formats across national borders (Grundy 2010: 303-7, Moran 2013). In 2010, Grundy was honoured by the Monte Carlo Television Industry Festival as the originator of the term and for its value as an early means of communicating the nature of formats to the television industry as a whole. However, the recognition was slightly curious given the conceptual coupling has not caught on either in the trade or in the field of critical research. It is, nevertheless, worthy of examination for two reasons. First, while somewhat unfashionable, it usefully encapsulates many of the versatile features of formats. Second, the term effectively highlights some of the limitations of the more current global/local formulation in accounting for the operation of formats as social, cultural and economic commodities.

To begin we turn to the international component of the term. As outlined above, television formats function as mobile, cross-border commodities - as templates that are theoretically capable of being remoulded and remade in any national or cultural setting. They are very often assumed (and marketed) as capable of bypassing differences of language, culture, history, religion and ethnicity. However, their unbounded characteristics are also precisely the feature that allows them to be parochialised. This capacity stems from four elements that are called into play in the process of adaptation (Moran and Malbon 2006: 64-9) 
- human labour, textual strategies, audience appeal and subsequent distribution. The first element emerges from the limited involvement of the original production team in the design of remakes in other places. While the contribution of the initial team varies between programmes, the reproduction of a format in a new territory will normally rely heavily on locally sourced personnel (Moran 2009a: 91-112). The second aspect of parochialisation arises from the customisation of programme content, so that the local version looks and sounds as though it was initiated where it is produced. The third element relates to the local audience reception of the re-versioned programme. Responding to the textual customizing that has taken place, recognising and accepting the familiar representations and references at work in the programme's images and sounds, the home audience is encouraged to accede to the programme as its own.

Finally, the fourth way in which the parochial dimension registers is through limited distribution. Some finished formats have proven capable of crossing national borders, such as American Idol which has been a primetime ratings success for Channel Ten in Australia alongside its own version of the format Australian Idol (Channel Ten 2013). In some cases, finished format imports have even eclipsed home-grown adaptations. For example, the UK version of the motoring show Top Gear has been far more popular than either of two attempted local remakes in Australia (Moran 2009a: 181, Ottley 2011). Esser (2010) highlights another more complicated instance of format multiplication with Next Top Model and its broadcast in the UK where four different versions were available to audiences (the US original as well as the versions from the UK, Canada and Australia). Formatted versions of programmes made in the US in particular have proven they can travel globally, but it is not typical for finished formats to move between markets and/or broadcasters in this way. This may be attributable to a number of factors including perceptions that the remake is too culturally specific to have appeal elsewhere, especially if there is already a locally-produced version. In short, while the format may be considered international, the finished programme version is often seen in audience and market terms as more circumscribed.

However, while parochial internationalism may be regarded as a shrewd designation of the apparently contradictory forces at work in this kind of commodity exchange, being parochial very often has very negative connotations. It is associated with ignorance, narrow mindedness and an inward focus while international is a term that now lacks currency. These factors may well have contributed to the term's neglect. Instead, the multiplicity of formats is more often delineated along global/local lines and it is to the analysis of these designations that we now turn.

\section{The Global/Local Nexus}

'Globalisation' has been much in vogue since the 1980s following profound changes in such areas as politics, finance, technology, communications and transportation. Global goes further than the terms that precede it, such as international or world-wide, in attempting to address the way in which cross-border interactions (in commerce, culture, politics and so on) now operate in ways that transcend traditional boundaries such as the nation (Robertson 1992: Giddens 2000; Rantanen 2005; Castells 2009). Like other researchers, we suggest that claims regarding the universality of globalisation are premature to say the least (Dahrendorf 1990, Ferguson 1993, Held 1989, Hirst and Thompson 1996). Nevertheless, the world certainly has changed. If we do not live in a globalised present, we at least inhabit a highly internationalized one. Take, for instance, the area of finance and business, one of several 
domains that appear to support the notion of a globalized world. Yet the fact remains that most companies trade from within distinct national economies. National policies continue to be necessary; indeed they may be regarded as indispensable in order to preserve the distinct styles and strengths of particular economic bases and the companies that trade from them (Hirst and Thompson 1995: 177-185).

Indeed, taking a more long-term, historical view of the matter, one might say that the era of 'globalisation' is only the latest in a succession of epochs of civilisations or world-systems, which themselves are marked by cycles of centralization as well as cycles of decentralization (Braudel 1982, 1995, 1996, Wallerstein 1980, 2011). In this context, it is worth recalling the historical dimensions of the internationalization of communications. For the origins of this linkage lie well before the early twentieth century and the advent of Hollywood, and even the nineteenth century development of the international submarine telegraphic cables and news agencies (Tunstall 1977; Wimseck and Pike 2007). Rather, its seed can be found in such events as the sixteenth century establishment of an international postal system and even the fifteenth century organization of a transnational book publishing industry in Western Europe (Febvre and Martin 1997, Noam 1991, 1991b, Tunstall 1977).

Problematising this notion of the global with regard to the television industry, and the influence and reach of formats in particular, is the fact that international trade, while impressive in terms of its value, is nevertheless dwarfed by the overall volume of programmes that only ever receive domestic circulation. Much of the world's television content is produced and broadcast within national broadcast systems and does not go on to have international distribution. Research on the global flow of television frequently fails to accord an integral place to this kind of 'local and regional' production. It is 20 years since O'Regan suggested that the amount spent on local production was 29 times greater than that spent on international audio-visual exchange (1992: 87). While the figure now needs readjustment, the observation still gives pause to the claims of cultural globalists and underlines the key role undertaken by nationally-based producers, broadcasters and audiences.

One final issue with the notion of the global has to do with what might be called the distribution fallacy. Proponents sometimes cite the apparent wide circulation of films, television programmes, music, and other cultural goods and practices as evidence for an increasing cultural homogeneity. However, such claims collapse important differences between marketing mechanisms on the one hand and social effects on the other. In the case of formats, such arguments also tend to discount the significance of the way in which programme templates are modified and remoulded to suit the specific target markets of broadcasters in different locations. In addition, distribution is nowhere near as universal in its reach as proponents of the cultural globalization argument would have us believe. Access to cultural commodities is highly skewed and influenced by factors such as population size, domestic wealth and geography, as well as structured inequalities based around the cultural backgrounds of caste, class or party, on ethnic cultures defended by bloodshed or kinship traditions linked to religious proscriptions (Alvarado 1996: 63-7, Ferguson 1993: 72).

If the term global raises questions when considered in relation to the territorial reach and cultural specificity of television formats, the same may be true of its conceptual running mate. What, then, might be meant by phrases such as local, localisation and localism? We suggest that the notion of the local, as the term is recurringly used in discussion of the domestication of programme formats is often closely linked with the structures of the national. 
While it is certainly highly problematic to attempt to conceptualize viewers as constituents of a 'national audience' (Esser 2010: 289), it is also the case that the frameworks that regulate broadcasting and the manner in which programme formats are licensed continues to centre around that of the nation.

Drawing on the concepts of nationhood expounded by Ernst Renan in 1882, Guibernau suggests a nation can be understood as 'a human group conscious of forming a community, sharing a common culture, attached to a clearly demarcated territory, having a common past and a common project for the future and claiming the right to rule itself' (1996: 47). However, nations do not exist simply as a result of self-determination or will. The apparatus of institutions, practices and beliefs that is known as the state is a crucial means whereby such a collectivity guarantees its own continuity. Television can be understood as one component of this state apparatus. Despite its expansion to include cable, satellite and digital distribution, this communications structure is not based around the activities of transnational media corporations but rather predominantly on agreements reached between nations in the nineteenth and twentieth centuries (Nowell-Smith 1991). Such a bulwark has been further strengthened by decisions taken at state level that affect such matters as television technology and restrictions on cross-border content transmission (Porter and Mun 2004: 593-6). Further, despite the emergence of narrowcasting and niche broadcasting, the majority of viewers within national boundaries continue to take much of their news and entertainment from the national broadcasting channels and networks (Buonanno 2012, Miller 2009, Moran 2009b, Turner 2009).

Emphasis on the national as the construct through which television is effectively theorised is also evident in a large body of television format research. Such was the case with Skovmand's early investigation into the local customising of the US Wheel of Fortune game show format in north west Europe including Sweden, Norway and Denmark (Skovmand 1992). This framing is continued with the recent publication of studies of the adaptation of the Pop Idol format in such territories as Bulgaria, the Peoples' Republic of China (PRC) and Nigeria (Zwan and de Bruin 2012). Similarly, inquiry into national identities is also facilitated by comparing local customisation of television programme formats across borders. Witness, for instance, such cross-national comparative studies of localisation and identity as those having to do with Big Brother (Banerjee 2002; FrauMeigs 2006; Mathijs and Jones 2004), Who Wants To Be A Millionaire? (Cooper-Chen 2005; Ganguly 2011), Pop Idol (Oren and Shahaf 2011 201-282; Zwan and de Bruin 2012), The Office (Larkey 2009; Beeden and de Bruin 2010), Ugly Betty (McCabe and Akass 2012) and the telenovela (Lippert 2011; Straubhaar 2011).

National television systems and the different broadcasters than operate within them inevitably produce cultural effects that, in turn, can help reinvigorate a kind of localism. Exposing a population within a given viewing territory to the same type of service can help to produce notions of commonality and shared experience. Moreover, instituting expectation of rhythms of service further ties national populations to the same flow of content (Attallah 1991: 77-9). This enculturation has the possibility of helping to promote a sense of community among a particular group of viewers within a national territory. But, of course, such communities are further secured by common assumptions having to do with language, ethnicity, religion, history and custom (Oren 2011). 


\section{Conclusions}

As this article has sought to demonstrate, television formats offer a very particular challenge in terms of the labels by which they can be appropriately described and understood in media geography terms. They possess a duality that is from an industry perspective complimentary, but in socio-cultural terms contradictory and complex. As an economic commodity they have a footloose but market-proven quality that underpins their appeal to television content producers and broadcasters alike. As a cultural artefact, formats are rooted specifically in spaces and times in which they are made, and often do not translate readily to other locations.

One of the challenges facing formatology, the emerging field of television format studies, is to achieve a stronger grasp on the alternating aspects of this kind of programme re-versioning. While the moment for parochial internationalism to achieve any kind of currency has long since past, it is also clear that the more popular global-local designations struggle to encapsulate the nuanced characteristics of television formats. 'Localisation' in particular is often intertwined with the national, a linkage that tends to be downplayed because of its apparent contradiction to notions of the global. We suggest there is a need for greater recognition of the local-national connection in understanding and assessing the structural parameters of format flows. However, we acknowledge that this pairing is not entirely unproblematic either, especially where audiences are concerned. This complexity underlines the need for ongoing refinement of the language we use to make sense of the economic and cultural geographies of formats.

\section{References}

Alvarado, M. (1996), 'Selling Television' in A. Moran ed. Film Policy: International, National and Regional Perspectives, London and New York: Routledge, pp. 62-71.

Attallah, P. (1991), 'Of homes and machines: TV, technology and fun in America, 1944-84', Continuum: An Australian Journal of the Media, 4(2), pp. 58-98.

Banerjee,I. (2002), 'The locals strike back? Media globalization and localization in the new Asian television landscape', Gazette: International Journal for Communication Studies, 64(6), pp.515-535.

Bazalgette, P. (2005), Billion Dollar Game: How Three Men Risked It All And Changed The Face Of Television. London and New York: Time Warner Books.

Beeden, A. and de Bruin, J. (2010) 'The Office: Articulations of National Identity in Television Format Adaptation', Television \& New Media, 11(1), pp. 3-19.

Bhagwati, J. (2004), In Defence of Globalization, New York: Oxford University Press.

Bielby, D. D. \& Harrington, C. L. (2008), Global TV: Exporting Television and Culture in the World Market, New York: New York University Press.

Braudel, F. (1982), On History, Chicago: University Of Chicago Press.

Braudel, F. (1995), A History of Civilizations (Reprint edition), London: Penguin Books.

Braudel, F. (1996), The Mediterranean: World in the Age of Philip II, Volume II, Berkeley, California: University of California Press.

Brzoznowski, K. (2011) 'Year in Review', TV Formats Weekly, January 3, pp.2-4.

Buonanno, M. (2012) Italian TV Drama and Beyond: Stories from the Soil, Stories from the Sea, Bristol and Chicago: Intellect.

Castells, M. (1996) Rise of The Network Society, Information Age Series Vol 1, London: Wiley-Blackwell. 
Castells, M. (2009), Communication Power, New York: Oxford University Press.

Chalaby, J. K. (2010), 'Broadcasting In a Post-National Environment: The Rise of Transnational TV Groups', Critical Studies in Television, 4(1), pp.39-51.

Channel Ten (2013), 'American Idol', http://ten.com.au/tvshows/americanidol.htm. Accessed 15 February 2013.

Cooper-Chen, A. (2005), “'A World of 'Millionaires': Global, Local and 'Glocal' TV Game Shows" in Cooper-Chen, A. (ed) Global Entertainment Media: Content, Audiences, Issues, Mahwah, NJ: Lawrence Erlbaum Associates pp. 191-209.

Dahrendorf R. (1990), Reflections on the Revolutions in Europe: It's a Letter Intended to Have Been Sent to a Gentleman in Warsaw, London: Chatto and Windus.

Esser, A. (2010) 'Television Formats: Primetime Staple, Global Market', Popular Communication, 8, pp.273-92.

Ferguson, M. (1993), 'The Mythology About Globalization', European Journal of Communications, 7(1), pp.69-93.

FrauMeigs, D. (2006), 'Big Brother and reality TV in Europe', European Journal of Communication 21(1), pp. 33-56.

Galtung, J. (1993), 'The role of communication in rethinking European identity', Media Development: Journal of the World Association for Christian Communication, $\mathrm{XL}(4)$, $\mathrm{pp}$. 3-7.

Ganguly, L. (2011) 'Global Television Formats and the Political Economy of Cultural Adaptation: Who Wants to Be a Millionaire? in India' in Oren, T. and S. Shahaf eds. Global Television Formats: Understanding Television Across Borders, New York and London: Routledge, pp. 323-345.

Giddens, A. (2000), Runaway World: How Globalization is Reshaping Our Lives. London: Routledge.

Goldsmith, B., Ward, S. and O'Regan, T. (2010), Local Hollywood Global Film Production and the Gold Coast, St Lucia University of Queensland Press.

Grundy, R. (2010), Reg Grundy, London and Sydney: Pier One Books.

Guback, T. (1969), The International Film Industry: Western Europe and America Since 1945, Bloomington: Indiana University Press.

Guibernau, M. (1996), Nationalisms: The Nation-State and Nationalism in the Twentieth Century, Cambridge: Polity.

Havens, T. (2006), Global Television Marketplace, London: British Film Institute.

Hirst, P. and Thompson, G. (1995), Globalisation in Question: The International Economy and the Possibilities of Governance, Cambridge: Polity Press.

Horsman, M. and A. Marshall (1994), After the Nation State, London: Harper Collins.

Hutcheon, L. (2006), A Theory of Adaptation, London: Routledge.

Larkey, E. (2009) 'Transcultural localization strategies of Global TV Formats: The Office and Stromberg' in Moran, A. (ed.) TV Formats Worldwide: Localizing Global Programs, Bristol and Chicago: Intellect, pp. 187-203.

Lippert, B. (2011), Telenovela Formats: Localized Versions of a Universal Love, Gottingen: Sierke Verlag.

Mathijs, E. and Jones J. (eds) (2004), Big Brother International: Formats, Critics and Publics, London, Wallflower Press.

McCabe, J. and Akass, K. (eds) (2012), Reading Ugly Betty: TV's Betty Goes Global, London: I.B. Taurus.

McLuhan, M. (1962), The Gutenberg Galaxy, New York: McGraw-Hill.

Middleton, R. (2000), The British Economy Since 1945: Engaging with the Debate, Basingstoke: Palgrave Macmillan. 
Miller, T. (1993), 'National identity and traded images', in Drummond, P., Patterson, R. and Willis, G. (eds), National Identity, London: British Film Institute, pp. 95-109.

Miller, T., Govil, N., McMurria, J. and Maxwell, R. (2001), Global Hollywood, London: British Film Institute.

Miller, T. (2009) 'Approach with caution and proceed with care: campaigning for the US presidency 'after' TV' in Turner, G. and Tay, J. (eds.) Television Studies After TV: Understanding Television in the Post-Broadcast Era, London and New York: Routledge, pp.75-82.

Moran, A. (1998), Copycat TV: Globalisation, Program Formats and Cultural Identity, Luton: University of Luton Press.

Moran, A. and Malbon, J. (2006) Understanding the Global TV Format, Bristol: Intellect.

Moran, A.,( 2009a), New Flows in Global TV, Bristol UK and Chicago USA: Intellect.

Moran, A. (2009b), 'Reasserting the national? Program formats, international television and domestic culture' inTurner, G. and Tay, J. (eds.) Television Studies After TV: Understanding Television in the Post-Broadcast Era, London and New York: Routledge, pp.149-158.

Moran A. (2013), TV Format Mogul: Reg Grundy's Transnational Career, Bristol and Chicago: Intellect.

Navarro, V. 2011 "More than Copycat Television: Format Adaptation as Performance" in Oren, T. and Shahaf, S. (eds.) Global Television Formats: Understanding Television Across Borders, New York and London: Routledge, pp. 23-38.

Noam, E. (1991), Telecommunications in Europe, New York: Oxford University Press.

Nowell-Smith, G. (1991), 'Broadcasting : National culture, international business', New Formations: Journal of Cultural History/Memory, 13.

Oren, T. (2011), 'Reiterational Texts and Global Imagination: Television Strikes Back' in Oren, T. and Shahaf, S. (eds.), Global Television Formats: Understanding Television Across Borders, New York and London: Routledge, pp. 366-381.

Oren, T. and Shahaf, S. (eds.) (2011), Global Television Formats: Understanding Television Across Borders, New York and London: Routledge.

O'Regan, T. (1993), 'The regional, the national and the local: Hollywood's new and declining audiences' in E. Jacka (ed.), Continental Shift: Culture and Globalisation, Sydney: Local Consumption Publication, pp.74-97.

Ottley, Stephen (2011), 'Local remake of BBC favourite becomes a car wreck', Sydney Morning Herald, 14 September, http://news.drive.com.au/drive/motor-news/topgear-australia-axed-20110914-1k8lc.html. Accessed 28 February 2013.

Porter, V. and Mun, S.H. (2004), 'Copyright Law and Television', in H. Newcomb (ed.), The Museum of Broadcast Communication Encyclopaedia of Television, Chicago: Fitzroy Dearborn, pp. 593-8.

Rantanen, I. (2005), The Media and Globalization, London: Sage.

Ritzer, G. (2004), The McDonaldization of Society, Thousand Oaks and London: Sage.

RobertsoN, R. (1992), Globalization - Social Theory and Global Culture, London: Sage.

Selznick, B. (2008), Global Television: Co-Producing Culture, Philadelphia: Temple University Press.

Skovmand, M. (1992), 'Barbarous TV international: Syndicated Wheels of Fortune' in Skovmand, M. and Schroeder, K.C. (eds.) Media Cultures: Reappraising Transnational Media, London: Routledge, pp.84-103.

Stetka, Vaclav (2012), 'From Global to (G)local: Changing Patterns of Television Program Flows and Audience Preferences in Central and Eastern Europe, Journal of Popular Film and Television, 40(3), pp.109-118. 
Straubhaar, J. (2011), 'Telenovelas in Brazil: From Travelling Scripts to a Genre and Proto-Format Both National And Transnational' in Oren, T. and Shahaf, S. (eds.) (2011), Global Television Formats: Understanding Television Across Borders, New York and London: Routledge, pp. 148-177.

Tunstall, J. (1977), The Media Are American, London: Constable.

Tunstall, J. (2008), The Media Were American: US Mass Media in Decline, New York \& Oxford: Oxford University Press.

Turner, G. (2009) 'Television and the nation: does this matter any more?' in Turner, G. and Tay, J. (eds.) Television Studies After TV: Understanding Television in the Post-Broadcast Era, London and New York: Routledge, pp. 54-64.

Waisbord, S. (2004), 'McTV? Understanding the Global Popularity of Television Formats', Television and New Media, 5(4),pp. 359-383.

Wallerstein, I. (1980), The Modern World-System II: Mercantilism and the Consolidation of the European World-Economy, 1600-1750, Studies in Social Discontinuity, London: Emerald Group Publishing Limited.

Wallerstein, I. (2011) The Modern World-System I: Capitalist Agriculture and the Origins of the European World-Economy in the Sixteenth Century, with a New Prologue (Reprint edition), Berkeley, California: University of California Press.

Zhang, H. (2011), 'Media Imperialism and Its Revisionist Approach Revisited: Towards a Synthesized Analytical Framework of Television Globalization in China', China Media Research, 7(1), pp. 112-124.

Zwan, K. and de Bruin, J. eds. (2012) Adapting Idols: Authenticity, Identity and Performance in a Global Television Format, Ashgate Publishing. 